\title{
The Age of Constitutions in the Americas
}

M C. Mirow

Florida International University College of Law, mirowm@fiu.edu

Follow this and additional works at: https://ecollections.law.fiu.edu/faculty_publications

Part of the Comparative and Foreign Law Commons, Constitutional Law Commons, Jurisprudence Commons, and the Legal History Commons

\section{Recommended Citation}

M. C. Mirow, The Age of Constitutions in the Americas, 32 Law \& Hist. Rev. 229-235 (2014). doi:10.1017/ S0738248014000054.

This Article is brought to you for free and open access by the Faculty Scholarship at eCollections. It has been accepted for inclusion in Faculty Publications by an authorized administrator of eCollections. For more information, please contact lisdavis@fiu.edu. 


\section{HEINONLINE}

Citation: 32 Law \& Hist. Rev. 2292014

Provided by:

FIU College of Law

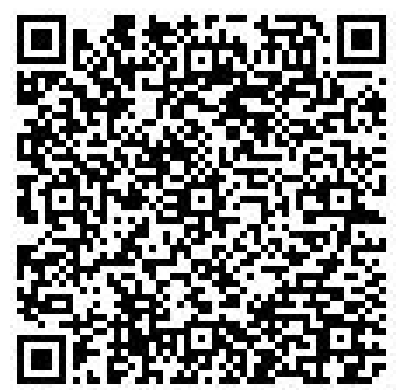

Content downloaded/printed from

HeinOnline (http://heinonline.org)

Thu Aug 25 12:41:29 2016

-- Your use of this HeinOnline PDF indicates your acceptance of HeinOnline's Terms and Conditions of the license agreement available at http://heinonline.org/HOL/License

-- The search text of this PDF is generated from uncorrected OCR text.

-- To obtain permission to use this article beyond the scope of your HeinOnline license, please use:

https://www.copyright.com/ccc/basicSearch.do? \&operation $=$ go\&search $\mathrm{Type}=0$ \&lastSearch $=$ simple\&all $=$ on\&titleOrStdNo $=0738-2480$ 


\title{
The Age of Constitutions in the Americas
}

\author{
M. C. MIROW
}

The late eighteenth and nineteenth centuries have been aptly called the "Age of Codifications." " The same period was also the Age of Constitutions. Although a great deal is known about the migration of prenational and transnational legal sources and ideas that led to national codes of civil and criminal law in Europe and the Americas, much less is known about similar processes on the constitutional level. ${ }^{2}$ Constitutional historians have been more parochial than their private law counterparts, most likely because of the relationship between constitutions and nations. In the light of independence, nations immediately needed constitutions to solidify gains and to consolidate state power. The study of these processes becomes national narratives, often in conversation with the former colonial power, which are disconnected from more general or regional trends. ${ }^{3}$ As Linda Colley's article in this issue illustrates, it is important to step back to view the constitution-making process from an Atlantic perspective that ties

1. Manlio Bellomo (trans. Lydia G. Cochrane), The Common Legal Past of Europe 1000 1800, 2nd ed. (Washington, DC: Catholic University of America Press, 1995), 1-33.

2. The practice of close textual analysis in European private law shifted seamlessly to legal history to provide detailed lineages of code provisions from Roman law, the ius commune, iura propria, and doctrinal works. See, for example, Alejandro Guzmán-Brito, Codificación del derecho civil e interpretación de las leyes: Las normas sobre interpretación de las leyes en los principales Códigos civiles europeo-occidentales y americanos emitidos hasta fines del siglo xix (Madrid: Iustel, 2011).

3. But see Juan Bautista Alberdi, Bases y puntos de partida para la organización política de la república argentina (Valparaíso: Imprenta del Mercurio, 185̦2; Buenos Aires: Ciudad Argentina, 1998). Alberdi prepared a critical and comparative analysis of the region's constitutions as a step towards the Argentine Constitution of 1853. He was particularly keen on the Constitution of California of 1849. Ibid, 4447 (1998).

M. C. Mirow is professor of law, Florida International University, Miami, Florida $<$ mirowm@fiu.edu>. 
the Americas, North and South, into the area of study. ${ }^{4}$ The Age of Constitutions in the Americas must include Latin America and the Caribbean.

Various initial works by Lauren Benton, Elizabeth Dale, Richard J. Ross, and others in the area coalesce to suggest this approach. Constitution making continued questions of empire, jurisdiction, sovereignty, and legal pluralism extant in preconstitutional or protoconstitutional orders. ${ }^{5}$ Benton has explored the complexities of the colonial Atlantic legal world whose institutions from the fifteenth through the end of the eighteenth centuries "stretch[ed] from the Iberian Americas, to Christian Europe, coastal and Islamic Africa, and into the vast Indian Ocean [to form] part of a single international regime."6 Similarly, in A Search for Sovereignty, Benton asks the reader to conceptualize "empire" as territorially porous, legally and spatially uneven, riddled with "corridors of control," and with vast areas of emptiness. ${ }^{7}$ In keeping with these cues, Dale urges a "legal history of the Americas" for the seventeenth century that reaches beyond British North America to consider "New Spain, New France, the New Netherlands, and Native Americans." ${ }^{\circ}$ An early experiment produced the contributions to The Many Legalities of Early America, and experiments in this vein have led to new understandings of the colonial world, such as Ross's explorations of legal communication. ${ }^{9}$ Similarly, Robert J. Cottrol's study of race in the Americas demonstrates the success of expanding our enquiries beyond national borders in the region. ${ }^{10}$ As suggested by these works and Colley's article, the approach

4. Linda Colley, "Empires of Writing: Britain, America and Constitutions, 1776-1848," Law and History Review 32 (2014).

5. Lauren Benton and Richard J. Ross, "Empires and Legal Pluralism: Jurisdiction, Sovereignty, and Political Imagination in the Early Modern World," in Legal Pluralism and Empires, 1500-1850, ed. Lauren Benton and Richard J. Ross (New York: New York University Press, 2013), 1-17.

6. Lauren Benton, Law and Colonial Cultures: Legal Regimes in World History, 1400 1900 (Cambridge: Cambridge University Press, 2002), 79.

7. Lauren Benton, A Search for Sovereignty: Law and Geography in European Empires, 1400-1900 (Cambridge: Cambridge University Press, 2010), 39, 103, 105, 279.

8. Elizabeth Dale, "Reconsidering the Seventeenth Century: Legal History in the Americas," in A Companion to American Legal History, ed. Sally E. Hadden and Alfred L. Brophy (London: Blackwell, 2013), 7.

9. Christopher L. Tomlins and Bruce H. Mann, eds., The Many Legalities of Early America (Chapel Hill: University of North Carolina Press, 2001); and Richard J. Ross, "Legal Communications and Imperial Governance: British North America and Spanish America Compared," in Cambridge History of Law in America, ed. Michael Grossberg and Christopher Tomlins (Cambridge: Cambridge University Press, 2008) 1:104-43.

10. Robert J. Cottrol, The Long, Lingering Shadow: Slavery, Race, and Law in the American Hemisphere (Athens: The University of Georgia Press, 2013). 
may be applied to questions of constitutional history. Written constitutions in this formative period were often a complicated response to the imperial legal pluralism revealed in these studies. ${ }^{11}$

What has to be considered in such an enquiry? Examining this Age of Constitutions, or as Colley puts it, this "contagion of constitutions," scholars must consider at least five essential collections of sources for this founding era of written constitutions. ${ }^{12}$ These are documents and accounts related to: (1) the United States Constitution and state constitutions, (2) English constitutional practices, (3) the French Revolution and the republic constitutions, (4) the Cortes of Cádiz and the Spanish Constitution of Cádiz of 1812, and (5) Haitian independence and the constitutions of the early republic. My purpose here is to sketch out a basic, minimal list of regional constitutional influences. There are many other early constitutions that could arguably be included in this list.

For the United States, seminal works by Robert R. Palmer, David Armitage, and others invoking Palmer's name for the period, "the Age of Revolutions," are addressed by Colley in the pages that follow. ${ }^{13}$ In keeping with the call for the examination of written texts, George Athan Billias's recent study of the impact of United States constitutionalism on global developments, admittedly a "pioneering effort," focuses on six texts, "the U.S. Constitution, . . . the Declaration of Independence, the first state constitutions, the Articles of Confederation, The Federalist, and the Bill of Rights." 14 Viewing them as a "simultaneous whole" for

11. See, for example, the discussion of the centrality of jurisdiction as it relates to the Spanish Constitution of Cádiz of 1812. Marta Lorente Sariñera, La nación y las españas: Representación y territorio en el constitucionalismo gaditano (Madrid: UAM Ediciones, 2010), 12-14; and Carlos Garriga and Marta Lorente, eds., Cádiz, 1812: La constitución jurisdiccional (Madrid: Centro de Estudios Políticos y Constitucionales, 2007).

12. In light of the contagion analogy, perhaps terms such as "transplant," "borrowing," and "migration," should be abandoned in favor of practices borrowed from epidemiology, so that the legal historian will undertake constitutional outbreak analysis using articles of constitutions and drafters' notes to identify marker constitutional strands. See Bernard Bailyn, The Ideological Origins of the American Revolution (Cambridge: Belknap Press of Harvard University Press, 1967), 230-319, ch. 6, "The Contagion of Liberty".

13. See, for example, David Armitage, The Declaration of Independence: A Global History (Cambridge: Harvard University Press, 2007); R.R. Palmer, The Age of Democratic Revolution: A Political History of Europe and America, 1760-1800, 2 vols. (Princeton: Princeton University Press, 1959-1964); and Sanjay Subrahmanyam and David Armitage, eds. The Age of Revolutions in Global Context, c.1760-1840 (New York: Palgrave Macmillan, 2010) as cited in Colley, "Empires of Writing," Law and History Review, 32 (2014). Therefore, this period was the Age of Codifications, the Age of Constitutions, and the Age of Revolutions.

14. George Athan Billias, American Constitutionalism Heard Round the World, 17761989: A Global Perspective (New York: New York University Press, 2009), xi. See also, 
comparative purposes, Billias traces and reports on seven chronological echoes in world constitutionalism. ${ }^{15}$ His first three echoes have some overlap with the Age of Constitutions discussed here. They deal with Europe from 1776 to 1800 , Latin America from 1811 to 1900, and Europe from 1800 to 1848 , and cover the influence of these texts in Belgium, France, Germany, Greece, Hungary, Italy, the Netherlands, Norway, Poland, Russia, Switzerland, and numerous countries of Latin America. ${ }^{16}$ This ambitious and useful work also reveals an important limit in the field: as concepts and structures move from one iteration to the next it becomes difficult to trace the source or inspirations directly to a known text within the corpus of constitutional materials.

Although the role of English constitutionalism in relationship to the United States is a central and well-explored theme for this period, its influence in other countries is much less understood. Colley's contribution significantly advances the scholarship in this area. She correctly notes the important place England, and specifically London, had as an intellectual hub for Latin American independence leaders and thinkers. ${ }^{17}$ She also explores Jeremy Bentham's activities peddling his constitutional wares to Latin America, an intriguing subject inviting further study, and illuminates John Cartwright's projects for home and abroad, including Buenos Aires, Colombia, Guatemala, Spain, and Mexico. ${ }^{18}$ Influences, however, were not always direct, as Billias reminds us, and an important path for English constitutionalism to other areas of the world was through Cádiz, where English models were frequently employed in the debates of the deputies. Active liberals in the Cortes, such as Gaspar Melchor de Jovellanos, were swayed by Lord Holland (Henry Richard Vassell Fox, Third Baron Holland) and the Scotsman Dr. John Allen to consider English models. Allen's work, Suggestion on the Cortes (1809), was subsequently published in part in Spanish. Other important liberal deputies at the Cortes, such as Agustin

Thomas Buergenthal, Jorge Mario García Laguardia, and Rodolfo Piza Rocafort, La constitución norteamericana y su influencia en latinoamérica (200 años 1787-1987) (San José, Costa Rica: CAPEL, 1987).

15. Billias, American Constitutionalism, 9, 376.

16. Billias, American Constitutionalism, 53-175.

17. Colley, "Empires of Writing," Law and History Review, 32 (2014).

18. Colley, "Empires of Writing," Law and History Review, 32 (2014). For Bentham and Latin America see, generally, Jeremy Bentham (ed. Philip Schofield), Colonies, Commerce, and Constitutional Law: Rid Yourselves of Ultramaria and other Writings on Spain and Spanish America (Oxford: Clarendon Press, 1995); Jeremias Bentham, Propuesta de código a todas las naciones que profesan opiniones liberales (Londres: Ed. Taylor, 1822); and Miriam Williford, Jeremy Bentham on Spanish America: An Account of his Letters and Proposals to the New World (Baton Rouge: Louisiana State University Press, 1980). 
Argüelles and the Conde de Toreno, were familiar with English constitutionalism through first-hand experiences in London. ${ }^{19}$

French Enlightenment political writings were everywhere in this period. For example, Spaniards and Latin Americans were well acquainted with the Declaration of the Rights of Man, the French constitutions, and the works of Montesquieu, Rousseau, and Sieyès. ${ }^{20}$ These sentiments were captured by Bolivar in 1819 in the context of Venezuelan independence and the common practice of looking to foreign sources for constitutional content:

Does not the Spirit of the Law say that it should be characteristic of the people who make it? that it is a great coincidence that the laws of one nation are able to suit another? ... that it ought to refer to the level of liberty the constitution may permit, to the religion of the inhabitants, to their inclinations, to their riches, to their number, to their commerce, to their customs, to their manner. Here is the code we ought to consult, not that of Washington! ${ }^{21}$

Although French sources were highly influential in constitutional thought in the period, conservatives and moderates reacted strongly against attempts to impose such ideas. For example, in 1818, Father Rafael de Vélez criticized the Spanish Constitution of Cádiz of 1812 by noting its similarity to the French Constitution of $1791 .{ }^{22}$

The Spanish Constitution of Cádiz of 1812 is itself another fundamental document of this period. ${ }^{23}$ It was, to borrow Bilder's term, a "transatlantic

19. Joaquin Varela Suanzes-Carpegna, Tres ensayos sobre historia constitucional (Lima: Universidad Inca Garcilaso de la Vega Cuadernos del Rectorado, 2008), 87-88, 127-131.

20. Ignacio Fernández Sarasola, La Constitución española de 1812 y su proyección europea e iberoamericana (Alicante: Biblioteca Virtual Miguel de Cervantes, 2004) http:/l www.cervantesvirtual.com/FichaObra.html?Ref $=12956 \&$ portal $=56$. See, generally, Chris Thomhill, A Sociology of Constitutions: Constitutions and State Legitimacy in Historical-Sociological Perspective (Cambridge: Cambridge University Press, 2011), 205230.

21. Simón Bolívar, Discurso ante el Congreso de Angostura, in Miguel Acosta Signés, Introducción a Simón Bolivar (México: Siglo Veintiuno Editores, 1983), 93. (Mirow's translation).

22. Fernández Sarasola, La Constitución española, n. 57. See also, Dante Figueroa, "Twenty-one Theses on the Legal Legacy of the French Revolution in Latin America," Georgia Journal of International and Comparative Law 39 (2010): 39-120 (asserting that the French Revolution was "the catalyst for the new Latin American nations' failings upon their independence." Ibid. 116.).

23. See, generally, Matthew C. Mirow, "Visions of Cádiz: The Constitution of 1812 in Historical and Constitutional Thought" Studies in Law, Politics, and Society 53 (2010): 59-88. The recent bicentennial of this constitution has produced a sizeable amount of scholarship and numerous international symposia. Fernando Reviriego Picón, La Constitución Española de 1812. Biliografia http://www.cervantesvirtual.com/obra-visor/ 
constitution." ${ }^{24}$ The political, military, and economic importance of America figured into its provisions as much as the importance of peninsular Spain, and its text was highly influential in Latin American constitutional developments. The trans-Atlantic aspects of this constitution, with its selective promulgation throughout the Spanish empire and its subsequent effects on Latin American constitutions, have been the subject of numerous studies. ${ }^{25}$ The drafting of its text, the text itself, and its implementation raise questions concerning this constitution's imperial aspirations, racial classification of citizens, maintenance of Catholicism as a state religion, notions of constitutional monarchy, and liberal ideology. The promulgation of the Constitution Cádiz in Florida provided residents of North America-Spaniards, Native Americans, Anglo-Americans, resident Europeans, slaves and others-an experience of a constitutional regime other than regimes based on the United States Constitution and state constitutions during this founding era. ${ }^{26}$

Just as London served as an intellectual hub, Cádiz was a center for constitutionalist thought that traveled the same uneven imperial paths described previously. Some former deputies at the Cortes in Cádiz returned to their nascent republics and went on to political service. They served in constitutional assemblies in their new countries. For example, Miguel Ramos Arispe was a key figure in the construction of the Mexican federal state, and José Joaquín Olmedo and Vicente Rocafuerte were subsequently presidents of Ecuador. ${ }^{27}$ José Miguel Gordoa y Barrio held various political positions after his return to Mexico and was a deputy to the Mexican

constitucion-de-cadiz-de-1812-bibliografia--0/html/000e led6-82b2-1 ldf-acc7-002185ce6064_2. html\#I 2_; Benjamín González Alonso, "Presentación," Anuario de Historia del Derecho Español 81 (2011): 9-10; Thomas Duve, "Verfassung und Verfassungsrecht in Latein-amerika im Licht des bicenteriario: Einleitung zur Debatte," Rechtsgeschichte 16 (2010): 16.

24. Mary Sarah Bilder, The Transatlantic Constitution: Colonial Legal Culture and the Empire (Cambridge: Harvard University Press, 2004).

25. See, for example, Manuel Chust, La cuestión nacional americana en las Cortes de Cádiz (Alzira: Centro Francisco Tomás y Valiente, 1999); Rafael Estrada Michel, Monarquía y nación entre Cádiz y Nueva España (México: Editorial Porrúa, 2006); Antonio-Filiu Franco, Cuba en los origenes del constitucionalismo español: La alternativa descentralizadora (1808-1837) (Zaragoza: Fundación Manuel Giménez Abad, 2011); Ivana Frasquet, Las caras del águila: Del liberalismo gaditano a la república federal mexicana (1820-1824) (Castelló de la Plana: Universitat Jaume 1, 2008); and Mario Rodriguez, The Cádiz Experiment in Central America, 1808-1826 (Berkeley: University of California Press, 1978). But also see Roberto Gargarella, Latin American Constitutionalism 1810-2010: The Engine Room of the Constitution (Oxford: Oxford University Press, 2013), 1-19 (placing the "“foundational period' of Latin American constitutionalism" in the mid-nineteenth century. Ibid, ix.)

26. M. C. Mirow, "The Constitution of Cádiz in Florida," Florida Journal of International Law 24 (2012): 271-329.

27. Marie Laure Rieu-Millan, Los diputados americanos en las Cortes de Cádiz (Madrid: Consejo Superior de Investigaciones Cientificas, 1990), 408. 
Constituent Congress in $1824 .^{28}$ Their constitutional experiences travelled with them to these newly independent countries.

Haitian independence was a recent political event that shaped constitutional thought during this period. In the Atlantic world, the fear caused by the Reign of Terror of the French Revolution was matched by accounts of the violence of the Haitian Revolution. The idea that a successful revolution might be led by slaves created panic in the minds of colonial leaders. ${ }^{29}$ The status of slavery and citizenship was addressed in light of this recent and, to the Atlantic élites, terrifying event. ${ }^{30}$ Provisions from Haitian constitutions were influential as texts that evoked reactions rather than emulation.

Constitutions were not only the product of contagion. Drafters also often appealed to the historicity of their proposed texts. Assertions of historicity provided a competing justification for new constitutional texts. Such assertions might reflect honest adaptations of prior practices or might be rhetorical devices to distance a text from foreign influences or claims of novelty. As Colley notes with reference to Daniel Hulsebosch, constitutions are constructed from imperial materials. Hulsebosch's assertion about American constitutionalism might easily be paraphrased for Latin America with only two changes: "Although crown officials and parliamentary legislation were gone, the legacies of Spanish rule-its legal institutions, practices, and languages-remained as the raw materials for the Latin American constitutions." 31 In the Age of Constitutions, drafters throughout the Americas .wrote new constitutions from the remains of empire and from the discrete texts that circulated throughout the region.

28. José Enciso Contreras, "Correspondencia de don José Miguel Gordoa, diputado a las Cortes de Cádiz, con la provincia de Zacatecas, 1811-1814," Anuario Mexicano de Historia del Derecho 22 (2010): 177-78.

29. Gargarella, Latin American Constitutionalism, 2-3.

30. Manuel Pérez Ledesma, "Las Cortes de Cádiz y la sociedad española," in Las Cortes de Cádiz, ed. Miguel Artola (Madrid: Marcial Pons, 2003), 184; and Rieu-Millan, Los diputados americanos, 151, 155. See, generally, Ada Ferrer, "Haiti, Free Soil, and Antislavery in the Revolutionary Atlantic," American Historical Review 117 (2012): 40-66; and Juan Marchena Ferñandez, "El día que los negros cantaron la marsellesa. El fracaso del liberalismo español en América, 1790-1823," Historia Caribe 2 (2002): 53-75.

31. Colley, "Empires of Writing," Law and History Review 32 (2014) quoting Daniel Hulsebosch, Constituting Empire: New York and the Transformation of Constitutionalism in the Atlantic World, 1664-1830 (Chapel Hill: University of North Carolina Press, 2005), 4. (Mirow's changes are in italics.) See, for example, M. C. Mirow, "Pre-Constitutional Law and Constitutions: Spanish Colonial Law and the Constitution of Cádiz," Washington University Global Studies Law Review 12 (2013): 313-37. 
$\infty$ 